\title{
Association of newly discovered IS elements with the dichloromethane utilization genes of methylotrophic bacteria
}

\author{
M. Schmid-Appert, K. Zoller, H. Traber, S. Vuilleumier and T. Leisinger
}

Author for correspondence: T. Leisinger. Tel: +411632 3324. Fax: +4116321148. e-mail: leisinger@micro.biol.ethz.ch

Mikrobiologisches Institut, Swiss Federal Institute of Technology, ETH-Zentrum, $\mathrm{CH}-8092$ Zürich Switzerland

\begin{abstract}
Dichloromethane (DCM) dehalogenases enable facultative methylotrophic bacteria to utilize DCM as sole carbon and energy source. DCM-degrading aerobic methylotrophic bacteria expressing a type A DCM dehalogenase were previously shown to share a conserved $4 \cdot 2 \mathrm{~kb}$ BamHI DNA fragment containing the dehalogenase structural gene, $\mathrm{dcm} A$, and $\mathrm{dcmR}$, the gene encoding a putative regulatory protein. Sequence analysis of a $10 \mathrm{~kb}$ DNA fragment including this region led to the identification of three types of insertion sequences identified as IS1354, IS1355 and IS1357, and also two ORFs, orf353 and orf192, of unknown function. Two identical copies of element IS 1354 flank the conserved $4.2 \mathrm{~kb}$ fragment as a direct repeat. The occurrence of these newly identified IS elements was shown to be limited to DCM-utilizing methylotrophs containing a type A DCM dehalogenase. The organization of the corresponding $\mathrm{dcm}$ regions in $12 \mathrm{DCM}$-utilizing strains was examined by hybridization analysis using IS-specific probes. Six different groups could be defined on the basis of the occurrence, position and copy number of IS sequences. All groups shared a conserved $5.6 \mathrm{~kb}$ core region with $\mathrm{dcmA}, \mathrm{dcmR}$, orf353 and orf192 as well as IS1357. One group of strains including Pseudomonas sp. DM1 contained two copies of this conserved core region. The high degree of sequence conservation observed within the genomic region responsible for DCM utilization and the occurrence of clusters of insertion sequences in the vicinity of the $\mathrm{dcm}$ genes suggest that a transposon is involved in the horizontal transfer of the DCM-utilization character among methylotrophic bacteria.
\end{abstract}

Keywords: dichloromethane, dehalogenase, IS element, methylotrophic bacteria

\section{INTRODUCTION}

Some Gram-negative facultative methylotrophic bacteria utilize dichloromethane (DCM) as the sole carbon and energy source. The initial step of DCM utilization is catalysed by DCM dehalogenase, an enzyme that transforms DCM to inorganic chloride and formaldehyde, a central metabolite of methylotrophic growth. Functionally and by their amino acid sequence, bacterial DCM dehalogenases belong to the Theta-class of the large and ubiquitous superfamily of glutathione $S$ transferases (Leisinger et al., 1994).

Abbreviations: DCM, dichloromethane; DIG, digoxigenin.

The GenBank/EMBL accession numbers for the sequences reported in this paper are X96995 and M32346.
Bacterial DCM dehalogenases have been shown to fall into two classes, type $A$ and type $B$, which significantly differ from each other with respect to kinetic properties and amino acid sequence (Scholtz et al., 1988; Bader \& Leisinger, 1994). In Methylobacterium sp. strain DM4 and other methylotrophs with a type A enzyme, the dehalogenase structural gene, $\operatorname{dcm} A$, and $\operatorname{dcmR}$, the gene encoding a regulatory protein governing dehalogenase expression (La Roche \& Leisinger, 1990, 1991), are located on a conserved $4.2 \mathrm{~kb} \mathrm{Bam} \mathrm{HI} \mathrm{fragment.} \mathrm{In}$ some strains, this fragment is carried on a $120 \mathrm{~kb}$ plasmid, whereas in others it is located on the chromosome (Leisinger et al., 1994). These findings and the observation that the ability of bacteria to utilize DCM is readily lost under non-selective conditions (Gälli \& Leisinger, 1988) suggest that the $d \mathrm{~cm}$ genes have been distributed among facultative methylotrophs by hori- 
zontal gene transfer. To explore this possibility in more detail, we have analysed in Methylobacterium sp. strain DM4 the DNA regions flanking the $d \mathrm{~cm}$ genes. Here we report that sequence similarity between a number of methylotrophs with a type A DCM dehalogenase extends over $10 \mathrm{~kb}$. This conserved region comprises, in addition to $d c m A$ and $d c m R$, two ORFs of unknown function as well as an assortment of newly discovered insertion sequences that appear to be specifically associated with the DCM utilization genes.

\section{METHODS}

Bacterial strains, plasmids and growth conditions. Bacterial strains and plasmids used in this work are listed in Table 1.
Methylotrophic bacteria were grown at $30^{\circ} \mathrm{C}$ in minimal medium with methanol or DCM as carbon sources as described elsewhere (Kohler-Staub et al., 1986). Escherichia coli strains were grown on LB medium (Miller, 1972) at $37^{\circ} \mathrm{C}$. Antibiotics for selection were added at the following concentrations: $200 \mu \mathrm{g}$ ampicillin $\mathrm{ml}^{-1}, 25 \mu \mathrm{g}$ tetracycline $\mathrm{ml}^{-1}$.

DNA manipulations. General genetic techniques were performed according to standard protocols (Ausubel et al., 1997; Sambrook et al., 1989). Plasmids were introduced into E. coli strains following the procedure described by Inoue et al. (1990).

Southern blot analysis. Digested genomic DNA was loaded on $1 \%$ agarose gels. The $1 \mathrm{~kb}$ DNA ladder used as molecular mass marker was labelled with digoxigenin (DIG)-dUTP. The 3 ' ends of the marker DNA were degraded by exonuclease

Table 1. Bacterial strains and plasmids used in this study

\begin{tabular}{|c|c|c|}
\hline Strain/plasmid & Relevant phenotype ${ }^{*} /$ genotype & Source/reference \\
\hline \multicolumn{3}{|l|}{ Methylobacterium } \\
\hline $\begin{array}{l}\text { Methylobacterium } \\
\text { extorquens AM1 }\end{array}$ & $\mathrm{Dcm}^{-}$ & Green (1992) \\
\hline $\begin{array}{l}\text { Metbylobacterium } \\
\text { organophilum } X X\end{array}$ & $\mathrm{Dcm}^{-}$ & Green (1992) \\
\hline Methylobacterium sp. DM4 & $\mathrm{Dcm}^{+}$ & Gälli \& Leisinger (1985) \\
\hline $\begin{array}{l}\text { Methylobacterium sp. } \\
\text { DM4-2cr }\end{array}$ & $\mathrm{Dcm}^{-}$ & Gälli \& Leisinger (1988) \\
\hline Methylobacterium sp. CM4 & $\mathrm{Dcm}^{-}$ & Doronina et al. (1996) \\
\hline \multicolumn{3}{|l|}{ Hyphomicrobium } \\
\hline Hyphomicrobium sp. GJ21 & $\mathrm{Dcm}^{+}$ & $\begin{array}{l}\text { D. Janssen, University of } \\
\text { Groningen, Netherlands }\end{array}$ \\
\hline Hyphomicrobium sp. DM2 & $\mathrm{Dcm}^{+}$ & Stucki et al. (1981) \\
\hline \multicolumn{3}{|l|}{ Methylophilus } \\
\hline Methylophilus sp. DM11 & $\mathrm{Dcm}^{+}$ & Scholtz et al. (1988) \\
\hline \multicolumn{3}{|l|}{ Pseudomonas } \\
\hline Pseudomonas sp. DM1 & $\mathrm{Dcm}^{+}$ & Brunner et al. (1980) \\
\hline \multicolumn{3}{|l|}{ Methylorhabdus } \\
\hline $\begin{array}{l}\text { Methylorhabdus } \\
\text { multivorans DM13 }\end{array}$ & $\mathrm{Dcm}^{+}$ & Doronina et al. (1995) \\
\hline \multicolumn{3}{|l|}{ Unidentified methylotrophs } \\
\hline Strains DM3, DM5-10 & $\mathrm{Dcm}^{+}$ & $\begin{array}{l}\text { Gälli \& Leisinger (1985), } \\
\text { Gälli (1986) }\end{array}$ \\
\hline \multicolumn{3}{|r|}{ ( } \\
\hline DH $5 \alpha$ & supE44 $\Delta l a c U 169$ ( $\Phi 80 l a c Z \Delta M 15)$ hsdR17 recA1 endA1 relA1 & Gibco-BRL \\
\hline$S 17-1$ & hsdR RP4-2 kan:: Tn5 tet ::MU chromosomally integrated & Simon et al. (1983) \\
\hline \multicolumn{3}{|c|}{ r } \\
\hline pBluescript $\mathrm{KS}(+)$ & $\mathrm{Ap}^{\mathrm{r}}$ & Stratagene \\
\hline pSUP202 & $\mathrm{Ap}^{\mathrm{r}}$, oriT from RP4 & Simon et al. (1983) \\
\hline pME1510 & $\begin{array}{l}\mathrm{Tc}^{\mathrm{r}}, \mathrm{Dcm}^{+},(\mathrm{pVK} 100), 21 \mathrm{~kb} \text { HindIII fragment } \\
\text { encompassing the Methylobacterium sp. DM4 } \mathrm{dcm} \text { region }\end{array}$ & Gälli \& Leisinger (1988) \\
\hline pME1540 & $\mathrm{Ap}^{\mathrm{r}},(\mathrm{pBLS}+), 1.5 \mathrm{~kb}$ HindIII-PstI fragment with $\operatorname{dcm} A$ & S. La Roche, unpublished \\
\hline pME1839 & $\mathrm{Ap}^{\mathrm{r}},(\mathrm{pBLS}+), 1 \cdot 1 \mathrm{~kb}$ EcoRI-SacI fragment of IS1354 $4_{\mathrm{L}}$ & Schmid-Appert (1996) \\
\hline pME1841 & $\begin{array}{l}\mathrm{Ap}^{\mathrm{r}},(\mathrm{pBLS}+), 2 \cdot 7 \mathrm{~kb} \text { Sacl-BamHI fragment with IS1355 and } \\
\text { IS1357 }\end{array}$ & Schmid-Appert (1996) \\
\hline pME1874 & $\mathrm{Ap}^{\mathrm{r}},(\mathrm{pSUP} 202), 21 \mathrm{~kb}$ HindIII fragment of pME1510 & Schmid-Appert (1996) \\
\hline pME1887 & $\mathrm{Ap}^{\mathrm{r}},(\mathrm{pBLS}+), 0.4 \mathrm{~kb}$ EcoRV fragment of IS1357 & Schmid-Appert (1996) \\
\hline
\end{tabular}

* $\mathrm{Dcm}^{+}, \mathrm{DCM}$-utilizing; $\mathrm{Dcm}^{-}$, unable to utilize DCM. 


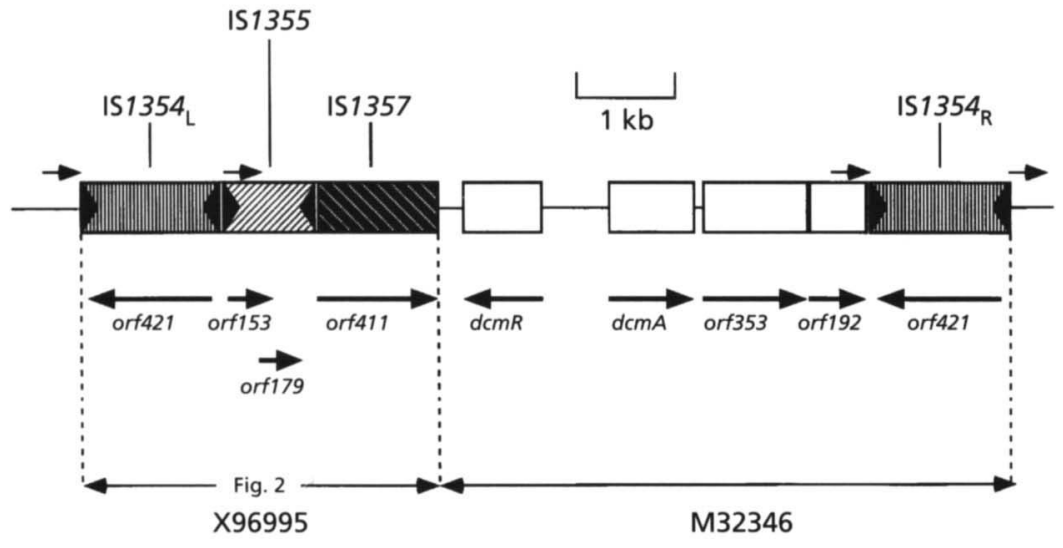

Fig. 1. Physical map of the $\mathrm{dcm}$ region of Methylobacterium sp. DM4. The genes dcmA and $\mathrm{dcmR}$ as well as the ORFs orf353 (pos. 2510-3538 in M32346) and orf192 (pos. 3573-4151 in M32346) are shown as white boxes. Insertion sequences are shown as hatched boxes. Arrows above ORFs indicate the direction of transcription of the corresponding coding regions. Black triangles at the ends of the boxes representing IS1355 and IS1354 sequences indicate the presence of inverted repeats, and the direct repeats found in the nucleotide sequences flanking $1 S 1354_{L}$ and $151354_{R}$ are shown as short arrows (see Fig. 2).

before labelling. For this purpose $10 \mu \mathrm{g} 1 \mathrm{~kb}$ DNA (Gibco BRL) were treated with 40 units T4 DNA polymerase for $2 \mathrm{~min}$ at $37^{\circ} \mathrm{C}$ in $20 \mu \mathrm{l} 53 \mathrm{mM}$ Tris acetate (pH 7.9), $66 \mathrm{mM}$ sodium acetate, $10 \mathrm{mM} \mathrm{MgCl}_{2}, 0.5 \mathrm{mM}$ DTT containing $0.1 \mathrm{mg} \mathrm{BSA} \mathrm{ml}^{-1}$. The re-synthesis reaction was carried out for 25 min at $37^{\circ} \mathrm{C}$ after addition of DIG-dUTP DNA-labelling mix (Boehringer). After electrophoresis, DNA was denatured and blotted on Hybond-N membranes (Amersham) as described by the manufacturer. DNA hybridization probes were labelled by PCR amplification with alkali-labile DIG-dUTP nucleotide mix. Specific DNA hybridization probes were obtained by standard protocols using $100 \mathrm{pmol}$ each primer and 3 fmol template DNA. The pBluescript $\mathrm{KS}(+)$ derivatives pME1839, pME1841, pME1887 and pME1540, carrying appropriate sequences from IS1354, IS1355, IS1357 and $\mathrm{dcmA}$ (Table 1), were used as DNA templates in the PCR reaction. The primers used to obtain specific DNA probes had the following nucleotide sequences (nucleotide positions in brackets refer to the sequence shown in Fig. 1): $5^{\prime}$ CGACGGCAACACGGT-3' (212-226), and 5'-GAGGGCATGACGACGGAATGGAAG-3' (1042-1019) for IS1354; 5' ACGGCACATTGGAGCGAA-3' (1772-1789) and 5'-ATAAAAGGCAACTGTAGT-3' (2390-2373) for IS1355; and universal primers 5'-ATTAACCCTCACTAAAGG-3' (T3) and $5^{\prime}$-AATACGACTCACTATAGG-3' (T7) for IS1357 and $\operatorname{dcm} A$, respectively. Hybridization at $68^{\circ} \mathrm{C}$ and subsequent immunochemical detection was performed following the procedure described by Engler-Blum et al. (1993). Probes were stripped from the membrane by alkali treatment for repeated hybridization of the same blot with probes of different specificity as described by the manufacturer.

DNA sequencing and sequence analysis. Fragments of the cosmid pME1510 were subcloned into pBluescript $\mathrm{KS}(+)$ for sequence analysis. DNA sequences were determined from double-stranded pBluescript subclones according to a modified chain-termination method (Schuurman \& Keulen, 1991). Nucleic acid and amino acid sequences were analysed by using the Genetics Computer Group program package, version 8.1 (University of Wisconsin, Madison, WI, USA). DNA and amino acid sequence similarity searches of nonredundant DNA and protein sequence databases were performed at the NCBI using the BLAST network service (Altschul et al., 1990) and the FASTA program, version 2.0.2 (Pearson, 1996). Sequence alignments were done with the GCG program PILEUP and identity scores were obtained from identity matrices of multiple sequence alignments calculated with the GCG program OLDDISTANCES. IS1354, IS1355 and IS1357 are
Plasmid Reference Centre listings (E. Lederberg, Stanford, CA, USA).

Mobilization of the $\mathrm{dcm}$ region into methylotrophs unable to utilize DCM. Exponentially growing cultures of donor (E. coli S17-1 containing plasmid pME1874) and recipient (Methylobacterium extorquens AM1, Methylobacterium organophilum XX, and Methylobacterium sp. CM4) were concentrated 40 -fold, mixed in a $1: 3$ ratio, spotted onto $L B$ agar and cocultivated at $30^{\circ} \mathrm{C}$ for $24 \mathrm{~h}$. Selection of transconjugants was carried out by streaking out onto minimal agar using DCM as sole carbon source.

\section{RESULTS}

\section{Sequence analysis of the Methylobacterium sp. DM4 dcm region}

The $d c m$ genes of Methylobacterium sp. DM4 are located on a $4.2 \mathrm{~kb}$ chromosomal Bam HI restriction fragment (La Roche \& Leisinger, 1990; Leisinger et al., 1994). A more detailed characterization of this region in Methylobacterium sp. DM4 and in Hyphomicrobium sp. DM2 by Southern analysis indicated that similarity between these strains extended to at least $10 \mathrm{~kb}$, and the corresponding region was cloned and sequenced from strain DM4. Fig. 1 gives an overview of the conserved region and indicates the location of newly sequenced DNA fragments. The region downstream of $\mathrm{dcm} A$ features two ORFs, orf353 and orf192, and IS1354. A second identical copy of this element is located at the left-hand border of the sequenced $\mathrm{dcm}$ region. IS1355 is found immediately adjacent to this element and is in turn followed by IS1357. The nucleotide sequence of the DNA fragment comprising the three newly identified insertion sequences is shown in Fig. 2, and the structural properties of these elements are summarized in Table 2.

The gene orf 353 located downstream (3') of $\mathrm{dcm} A$ (Fig. 1) encodes a putative protein with a molecular mass of $40 \mathrm{kDa}$. Its sequence was preceded by a putative RBS but lacked sequences with similarity to $E$. coli consensus promoters or Methylobacterium promoter motifs. A database search for similar proteins gave $45 \%$ identity of Orf353 with OrfA, the deduced product of an 


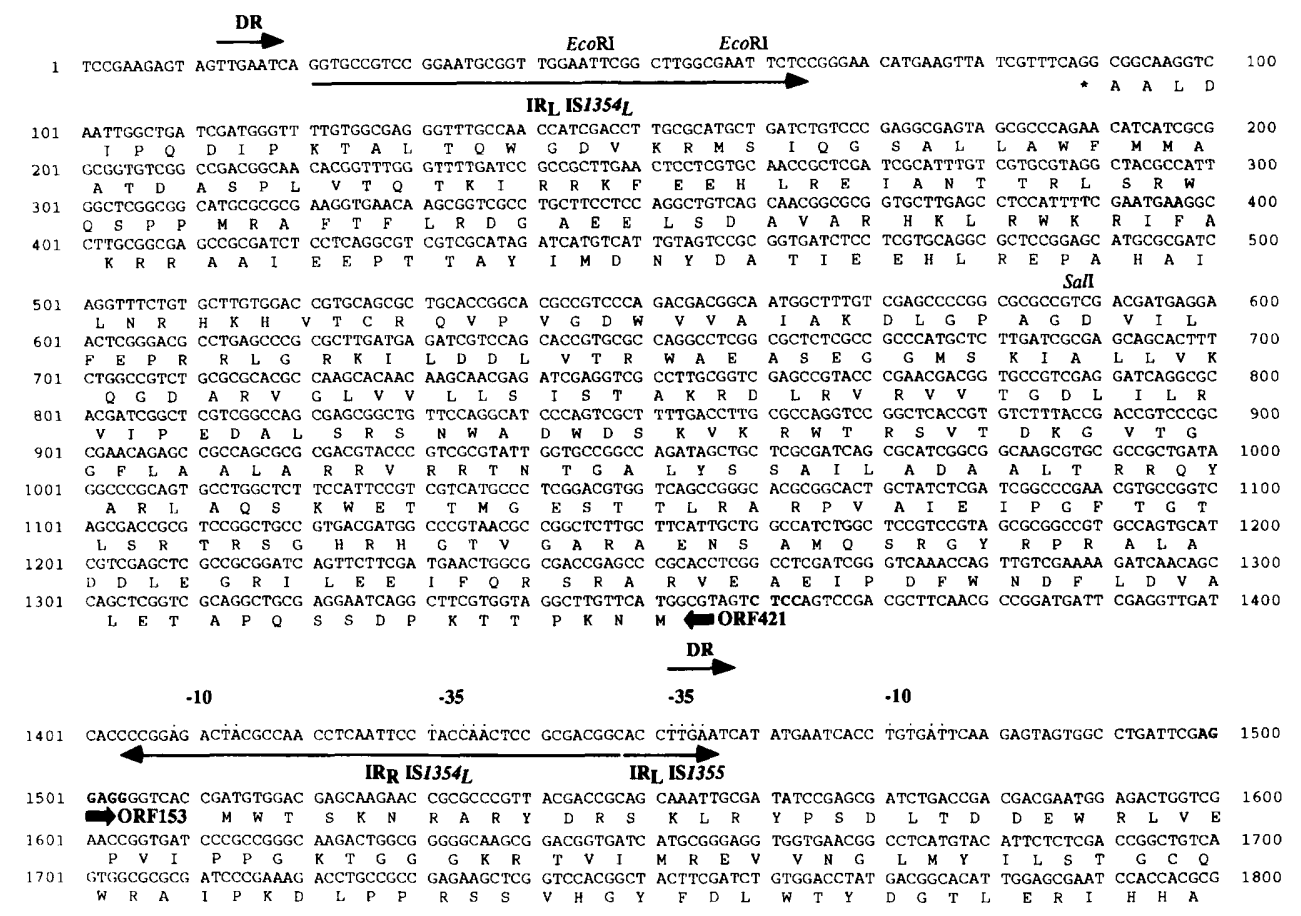

Putative frameshif signal

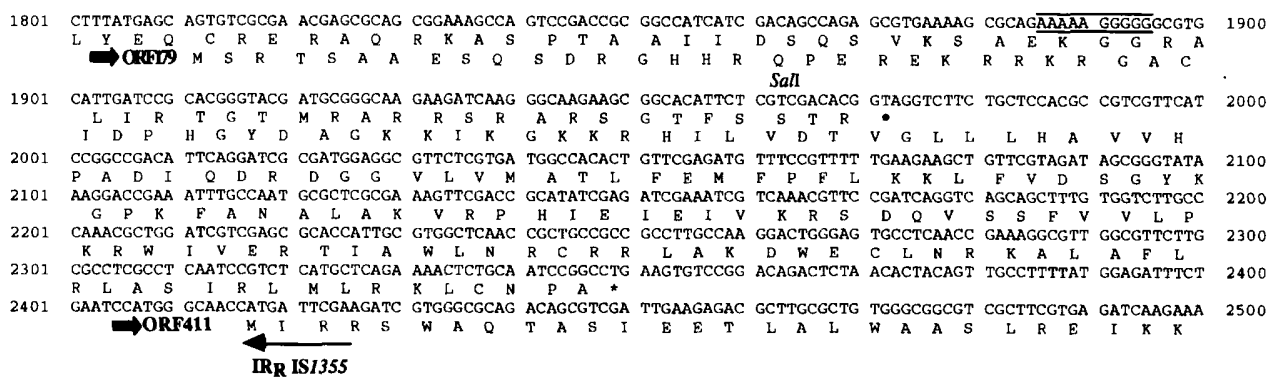

2501 CGGATACGTC CGTTGTTCAA TCAAGATCGC GTTGCGAGGA ATGCAGGCTT GTTCCTGGAA GGCCTTCTCG GAGATGAGCA ACGCAAAACC GGCTGGATGC 2600

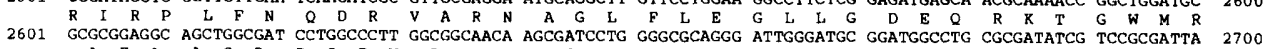

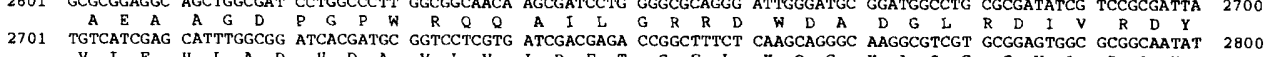

2701 TGTCATCGAG CATTTGGCGG ATCACGATGC GGTCCTCGTG ATCGACGAGA

2801 ACTGGTTCCG CGGGCAAGAT CACGAACTGC CAGATTGGCG TCTTCGCTGC CTACGTATCG CGCCACGGTC ATGCGTTCAT CGATCGCGCG CTGTATCTTC 2900

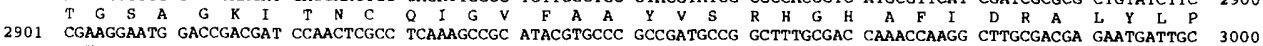

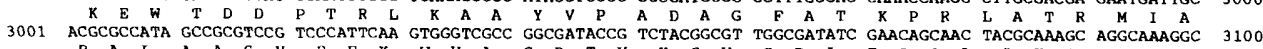

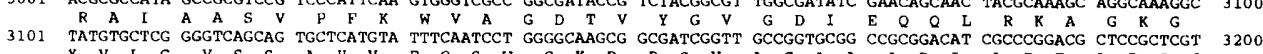

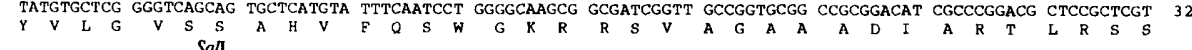

3201 CCGACTGGAA AAGCCTGTCG ACAGGGGCCG GAACCAAAGG ACCGCGGCTG CATGATTGGT GCTATCTCGA GTTGGCCGAT CTAGAAGTCG AAGAATCAAA 3300

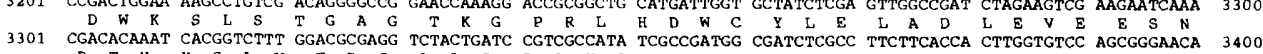

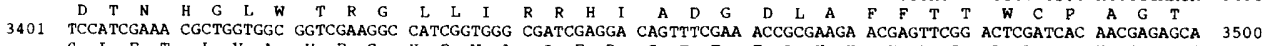

3401 TCCATCGAAA CGCTGGTGGC GGTCGAAGGC CATCGGTGGG CGATCGAGGA CAGTTTCGAA ACCGCGAAGA ACGAGTTCG ACTCGATCAC AACGAGAGCA 3500

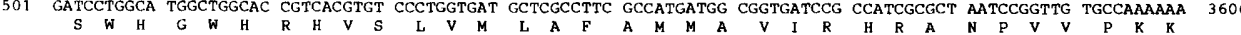

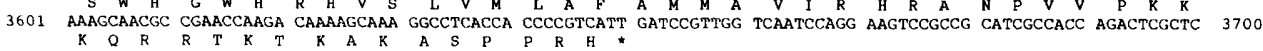

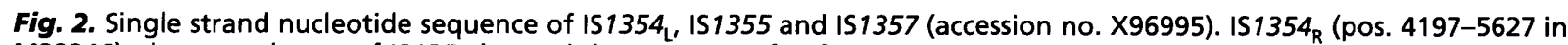
M32346), the second copy of IS1354 located downstream of orf192 in strain DM4, is identical to IS1354. Inverted repeats (IR) and direct repeats (DR) at both ends of an insertion sequence are indicated by arrows below and above the sequence, respectively. Translational products of the putative transposase genes are given below the nucleotide sequence. Stop codons are indicated by asterisks. Potential RBSs are in bold. Identities to the $-35 /-10$ promoter consensus of $E$. coli are indicated by dots. The putative frameshift signal in IS1355 is indicated by lines above and below the sequence. Boxed nucleotides accompanied by lettered numerals depict a possible pseudoknot RNA secondary structure downstream of the putative frameshift signal (Farabaugh, 1996; see text). Residues in bold in Orf153 and Orf179 indicate the potential translation frameshifting site leading to the Orf153-Orf179 fusion protein. Underlined residues in the sequence of Orf421 correspond to the D-(3)-G-(HVMF)-(6)-(STAV)-(LIVMFVW)-(PT)-(1)-(STAV)-(2)-Q-R-C-(2)$H$ 'mutator' motif (Eisen et al., 1994) found in all IS1354-related transposases. 
Table 2. Insertion sequences IS1354, IS1355 and IS1357 of Methylobacterium sp. strain DM4

\begin{tabular}{|lcccc|}
\hline IS element & $\begin{array}{c}\text { Length } \\
(\mathbf{b p})\end{array}$ & Transposase & $\begin{array}{c}\text { Inverted repeat } \\
(\mathbf{b p})\end{array}$ & $\begin{array}{c}\text { Direct repeat } \\
(\mathbf{b p})\end{array}$ \\
\hline IS1354 & 1431 & ORF421 & 48 & 8 \\
IS1355 & 975 & ORF153 & $9-10$ & ND $^{*}$ \\
IS1357 & & ORF179 & & ND $^{*}$ \\
\hline
\end{tabular}

*ND, Not determined. The length of these sequences could not be determined, presumably due to sequence overlap between IS1354 and IS1355 and between IS1355 and IS1357.

incomplete ORF downstream (3') of the $\operatorname{dcm} A$ gene of Methylophilus sp. strain DM11 (Bader \& Leisinger, 1994). This suggests that the clustering of $d c m A$ with orf 353 is an evolutionarily conserved trait, but the function of the proteins encoded by orf353 or orfA remains obscure. Deletion of orf353 had no effect on DCM utilization (Schmid-Appert, 1996) so these genes do not appear to be involved in DCM metabolism. A modest level of $27 \%$ amino acid identity was also noted between Orf353 and protein P8 of Nocardia lactamdurans. Protein P8 is one of the proteins implicated in converting cephalosporin $\mathrm{C}$ to 7 -methoxycephalosporin C (Coque et al., 1995), but it is unclear if this reaction relates in any way to dihalomethane metabolism.

A second ORF, orf192, was also found downstream of orf 353 . The corresponding $21 \mathrm{kDa}$ protein sequence showed no significant identity to known sequences. As for orf 353, a putative RBS was detected in the region immediately upstream of this reading frame but no promoter sequences could be found.

\section{Characteristics of IS1354}

IS1354 extended over $1431 \mathrm{bp}$ and carried $48 \mathrm{bp}$ imperfect terminal inverted repeats which were flanked by 8 bp direct repeats. These flanking sequence repetitions, 5'-TTGAATCA-3' for IS1354 ${ }_{\mathrm{L}}$ and $5^{\prime}$-GCCGTCAA-3' for IS1354 $4_{R}$, were not identical for the two copies of the element. The major ORF of IS1354 encoded a putative protein of 421 amino acids, termed Orf421. It was preceded by a putative $-35 /-10$ promoter region and a potential RBS (Fig. 2). Orf421 exhibited similarity to putative transposases of insertion sequences from both Gram-positive and Gram-negative bacteria (Table 3). Sequence alignments of Orf 421 to related transposases (not shown) led to the identification of a conserved Cterminal motif corresponding to the consensus sequence described by Eisen et al. (1994) for a family of insertion sequences including elements of plants and bacteria (Fig. 2). The size of IS1354-related elements described in the literature ranges from 1.3 to $1.7 \mathrm{~kb}$. Upon insertion, they give rise to $7-9 \mathrm{bp}$ direct repeats of the target site, and carry $15-41$ bp inverted repeats at their extremities. Like IS1354, these elements contain a single ORF encoding a potential transposase composed of between 296 and 474 amino acids. Most of the insertion sequences hom- ologous to IS1354 are present as multiple copies in their host strains. No sequence similarities between the target sites of these copies have been observed so that insertion of these elements is thought to be non-specific (Guilhot et al., 1992; Yates et al., 1988).

\section{Characteristics of IS1355}

IS1355 was $975 \mathrm{bp}$ in length and had 9 and $10 \mathrm{bp}$ terminal inverted repeats. No sequence duplications were observed in the flanking DNA. This was possibly caused by the subsequent insertion of IS1354 next to IS1355 since the $9 \mathrm{bp}$ inverted repeat at the left end of IS1355 was identified within the $8 \mathrm{bp}$ direct repeat flanking IS1354 (Fig. 2).

The nucleotide sequence of IS1355 revealed a short ORF, orf153, between nucleotides 61 and 520 in IS1355. It was partly overlapped by orf 179 , which was shifted in phase of translation by -1 nucleotide and extended from nucleotide positions 380-897 in IS1355. While orf 153 was preceded by a potential $-10 /-35$ promoter and by a putative RBS (Fig. 2), none of these structures was observed in the region $5^{\prime}$ of orf 179 . Sequences similar to both Orf153 and Orf179 were found within a subgroup of the large IS5/IS4 family of insertion sequences (Rezsöhazy et al., 1993). Similar transposase sequences in this group are also often encoded by two overlapping ORFs (Rezsöhazy et al., 1993). The sequence 5 -AAAAAGGGGG-3' found in the region where orf153 and orf179 overlap (Fig. 2) was very similar to potential ribosomal frameshifting signal sequences described by Iversen et al. (1994) for IS1355related IS elements. These signals are known to direct the formation of fusion proteins as the result of -1 translational frameshifting with simultaneous slippage (Chandler \& Fayet, 1993; Farabaugh, 1996). Accordingly, a frameshifting event at position 1894 of the IS1355 nucleotide sequence (Fig. 2) would result in a hypothetical fusion protein Orf153-Orf179 with a higher degree of identity to IS1355-related transposases encoded by one single reading frame than the polypeptides derived separately from orf 153 and orf 179 (Table 3). Interestingly, the genome of the cyanobacterium Synechocystis sp. strain PCC 6803, the sequence of which was recently reported (Kaneko et al., 
Table 3. Similarity of IS1354, IS1355 and IS1357 of Methylobacterium Sp. DM4 to other insertion sequences

\begin{tabular}{|c|c|c|c|c|c|c|c|c|}
\hline \multirow{4}{*}{ Organism } & \multicolumn{3}{|c|}{ Insertion sequence } & \multirow{2}{*}{\multicolumn{5}{|c|}{$\begin{array}{c}\text { Putative transposases of Methylobacterium sp. } \\
\text { DM4 IS elements } \\
\text { (percentage amino acid identity) }\end{array}$}} \\
\hline & \multirow[t]{3}{*}{ Element } & \multirow[t]{3}{*}{ Reference } & \multirow[t]{3}{*}{ Protein acc. no.* } & & \multirow{2}{*}{\multicolumn{3}{|c|}{ IS1355 }} & \multirow{3}{*}{$\frac{\text { IS } 1357}{\text { Orf411 }}$} \\
\hline & & & & \multirow{2}{*}{$\begin{array}{c}\text { IS1354 } \\
\text { Orf421 }\end{array}$} & & & & \\
\hline & & & & & Orf153 & Orf179 & $\begin{array}{l}\text { Orf153- } \\
\text { Orf179† }\end{array}$ & \\
\hline Clostridium perfringens & IS1151 & $\begin{array}{l}\text { Daube et al. } \\
(1993)\end{array}$ & S31644 & $27 \cdot 1$ & & & & \\
\hline Mycobacterium smegmatis & IS6120 & $\begin{array}{l}\text { Guilhot et al. } \\
\text { (1992) }\end{array}$ & P35883 & $26 \cdot 3$ & & & & \\
\hline Sinorbizobium meliloti & ISR $m 5$ & $\begin{array}{l}\text { Laberge et al. } \\
\text { (1995) }\end{array}$ & Q52873 & $25 \cdot 6$ & & & & \\
\hline Burkholderia cepacia & IS406 & Wood et al. (1991) & $\mathrm{P} 24575$ & $25 \cdot 5$ & & & & \\
\hline Streptococcus thermophilus & IS1191 & $\begin{array}{l}\text { Guédon et al. } \\
\text { (1995) }\end{array}$ & Q56104 & $24 \cdot 3$ & & & & \\
\hline Mycobacterium avium & IS1245 & $\begin{array}{l}\text { Guerrero et al. } \\
(1995)\end{array}$ & Q48368 & $24 \cdot 2$ & & & & \\
\hline Acetobacter xylinum & IS1032 & $\begin{array}{l}\text { Iversen } \text { et al. } \\
\quad(1994)\end{array}$ & Q44566 & & $40 \cdot 3$ & $48 \cdot 9$ & $51 \cdot 6$ & \\
\hline Acetobacter xylinum & IS1031c & Coucheron (1993) & Q44579 & & $44 \cdot 2$ & $44 \cdot 4$ & $50 \cdot 9$ & \\
\hline Sinorhizobium meliloti & ISR $m 4$ & Soto et al. (1992) & Q52958 $\ddagger(X 65471)$ & & $46 \cdot 8$ & $40 \cdot 6$ & $49 \cdot 8 \rrbracket$ & \\
\hline $\begin{array}{l}\text { Synechocystis sp. PCC } \\
6803\end{array}$ & $\begin{array}{l}\text { HSll1791/ } \\
1792 \$ \|\end{array}$ & $\begin{array}{l}\text { Kaneko et al. } \\
\text { (1996) }\end{array}$ & (D90905) & & $45 \cdot 0$ & $37 \cdot 1$ & $41 \cdot 9$ & \\
\hline $\begin{array}{l}\text { Synechocystis sp. PCC } \\
6803\end{array}$ & Slr0350\$ & $\begin{array}{l}\text { Kaneko et al. } \\
(1996)\end{array}$ & Q57495 & & $35 \cdot 1$ & $33 \cdot 3$ & $40 \cdot 5$ & \\
\hline $\begin{array}{l}\text { Synechocystis sp. PCC } \\
6803\end{array}$ & $\begin{array}{r}\text { Slr0799/ } \\
0800 \$ \|\end{array}$ & $\begin{array}{l}\text { Kaneko et al. } \\
\text { (1996) }\end{array}$ & Q55944/Q55945 & & $45 \cdot 4$ & $35 \cdot 4$ & $40 \cdot 0 \$$ & \\
\hline Streptomyces lividans & $\operatorname{Tn} 4811$ & Chen et al. (1992) & Q54404 & & $33 \cdot 8$ & $32 \cdot 8$ & $37 \cdot 6$ & \\
\hline Burkholderia cepacia & IS402\$ & $\begin{array}{l}\text { Ferrante \& Lessie } \\
\text { (1991) }\end{array}$ & P24537/P24536 & & $21 \cdot 1$ & $18 \cdot 9$ & $22 \cdot 4 \$$ & \\
\hline Agrobacterium tumefaciens & IS427\$ & $\begin{array}{l}\text { De Meirsman } \\
\text { et al. }(1990)\end{array}$ & Q44425/PQ0496 & & $22 \cdot 5$ & $18 \cdot 0$ & $21.9 \$$ & \\
\hline $\begin{array}{l}\text { Synechocystis sp. PCC } \\
6893\end{array}$ & HS110667\| & $\begin{array}{l}\text { Kaneko et al. } \\
\text { (1996) }\end{array}$ & Q55974 & & & & & $24 \cdot 7$ \\
\hline $\begin{array}{l}\text { Synechocystis sp. PCC } \\
6803\end{array}$ & HSllo092\| & $\begin{array}{l}\text { Kaneko et al. } \\
\text { (1996) }\end{array}$ & Q55893 & & & & & $21 \cdot 0$ \\
\hline $\begin{array}{l}\text { Synechocystis sp. PCC } \\
6803\end{array}$ & Slr0099\| & $\begin{array}{l}\text { Kaneko et al. } \\
\text { (1996) }\end{array}$ & Q55871 & & & & & $20 \cdot 6$ \\
\hline Calothrix sp. PCC 7601 & IS701 & Mazel et al. (1991) & Q00461 & & & & & $19 \cdot 0$ \\
\hline
\end{tabular}

*Protein database accession numbers; if not available, the gene entry accession number is given in parentheses.

† The hypothetical fusion protein Orf153-Orf179 results from a -1 translation frameshifting event with simultaneous slippage at position 1894 of the IS1355 nucleotide sequence (see text and Fig. 3).

¥ The ISR $m 4$ sequence used here was proposed by Iversen et al. (1994). The introduction of a 1 nucleotide gap yields one continuous ORF with overall higher similarity to this group of transposase sequences.

\Putative transposases related to IS1355 which appear to be encoding by two overlapping ORFs. Observed putative frameshift sequences: AAAAAAGGGGG (HSll1791/HSll1792, Slr0799/slr0800), AAAAACTGG (IS402), AAAAAGGGGG (IS427).

|| Putative transposases of Synechocystis as annotated by Kaneko et al. (1996). The presence of insertion sequence structures enclosing the corresponding ORFs remains to be demonstrated.

I Four other identical putative transposase sequences and at least six further sequences differing only in a few amino acids are found in the Synechocystis sp. PCC 6803 genome.

1996), features many genes encoding putative transposase proteins similar to orf153 and orf 179 , both as single full-length ORFs and as overlapping ORFs. With regard to the latter, very similar putative frameshift signals to that found in IS1355 were found in at least two other cases (see Table 3). 
(a)

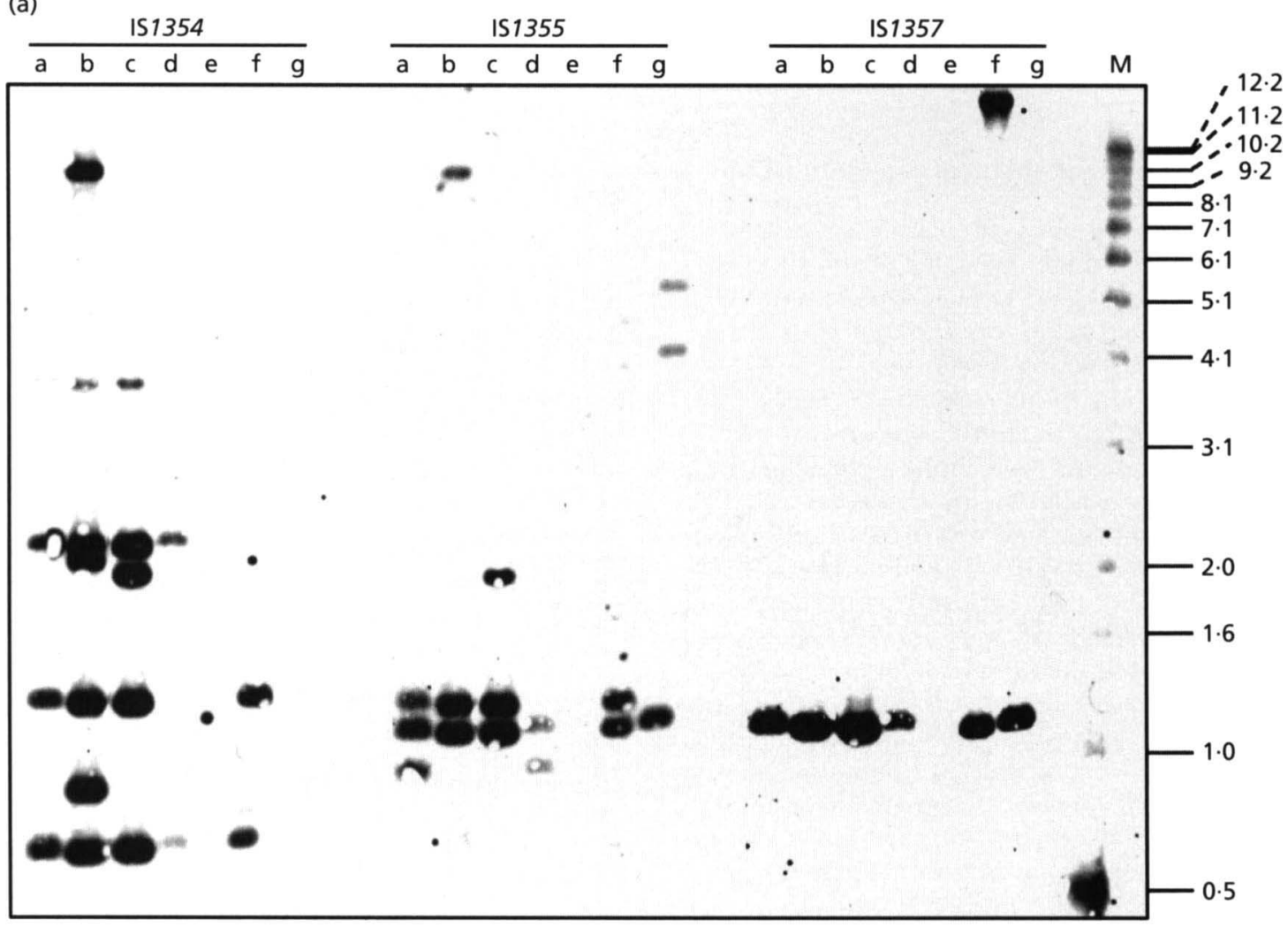

(b)
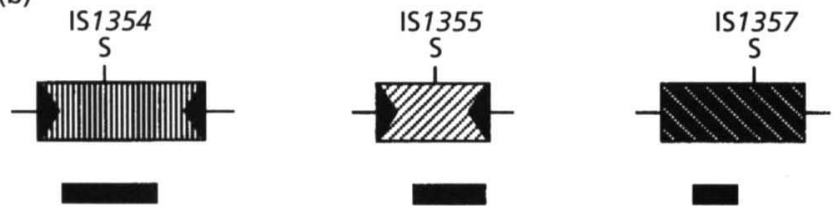

Fig. 3. Detection of IS1354, IS1355 and IS1357 in total DNA of various DCM-utilizing methylotrophs. The same membrane was hybridized in turn with DIG-labelled probes specific for each insertion element. (a) Southern analysis of Sall-digested total DNA from strain DM1 (lane a), DM2 (lane b), DM4 (lane c), DM5 (lane d), DM11 (lane e), DM13 (lane f), GJ21 (lane g) with DIG-labelled probes of IS1354, IS1355 and IS1357. Fragment sizes of the DNA marker are indicated in kb. (b) Schematic representation of the specific probes used for hybridization. IS1354, IS1355 and IS1357 are shown as hatched boxes. Black bars below the boxes depict the size and position of the IS-specific probes used to detect IS1354, IS1355 and 151357, respectively. Element-internal Sall sites $(\mathrm{S})$ are indicated.

\section{IS1357, an incomplete insertion sequence}

IS1357, the third insertion sequence in the $d c m$ region of Methylobacterium sp. DM4, was located adjacent to the right hand end of IS1355 (Fig. 2). The nucleotide sequence of this element contained orf411, an ORF whose $5^{\prime}$ region lacks a potential promoter structure and RBS. The polypeptide potentially encoded by orf 411 exhibited a rather low level of identity of about $20 \%$ with putative transposases found in cyanobacteria (Table 3). Since the start of the orf 411 sequence overlapped with the right-hand extremity of IS1355, the product of orf 411 may have been truncated by insertion of IS1355 into IS1357. The fact that it was not possible to identify the ends of IS1357 would be consistent with such an insertion event.

\section{Occurrence of the novel insertion sequences in methylotrophic bacteria}

The distribution of the newly discovered insertion sequences among various methylotrophic bacteria was examined by Southern hybridization with the probes indicated in Fig. 3(b). The 12 DCM-utilizing methylotrophs with type A DCM dehalogenases contained copies of at least two different insertion sequences. In contrast, no hybridization signal was detected in total DNA of two Methylobacterium strains unable to grow with DCM, or in DNA of Methylobacterium sp. strain DM4-2cr (Gälli \& Leisinger, 1988; Table 1), a temperature-cured mutant of strain DM4 which has suffered a deletion of the entire $\mathrm{dcm}$ region (data not shown). The three insertion sequences were also absent 
from DNA of Methylophilus sp. strain DM11, an organism expressing a type B DCM dehalogenase (Fig. 3).

\section{Organizational patterns of the $\mathrm{dcm}$ region in DCM- utilizing bacteria}

Southern analysis under high stringency conditions was used to examine in more detail the arrangement of the IS elements and the $\mathrm{dcm}$ genes on the genomes of the DCM-utilizing bacteria with a type A dehalogenase. An example of a hybridization experiment with Salldigested total DNA of representative strains is shown in Fig. 3. Similar experiments were done with DNA that had been digested with BamHI, BglII, EcoRI and PstI (data not shown). SalI-digested DNA of strains DM1, DM3, DM6, DM9 and DM10, as well as DM5, DM7 and DM8, revealed identical hybridization patterns, and only representative hybridizations with DNA of strains DM1 and DM5 are presented (Fig. 3a, lanes a and d). In the case of Sall-digested DNA of strain DM1, the relatively strong hybridization signals obtained at about $0.8 \mathrm{~kb}$ with the IS1354 probe, and at about $1.3 \mathrm{~kb}$ with the IS1355 and IS1357 probes, respectively, suggested the presence of two hybridizing fragments of identical size in strains of the DM1 class. Additional hybridization experiments with EcoRI and BglII-digested DNA then confirmed the presence in two copies of all three IS elements in strains of this class (data not shown). It thus became clear that strains DM1, DM3, DM6, DM9 and DM10 contained two copies of the $d \mathrm{~cm}$ region. Fig. 4 presents a hybridization experiment of BglII- and PstIdigested DNA carried out to unambiguously identify the two copies of the DCM dehalogenase gene in strain DM1. Since the $\mathrm{dcm}$ region had no restriction site for these enzymes, a single hybridizing band was expected, and found, for each copy of the $\mathrm{dcm}$ gene region.

Further, the larger number of hybridizing bands observed in the DNA of strains DM2 and DM13 with IS1354 and IS1357 probes, respectively, indicated that extra copies of these elements were present in these strains (Fig. 3a, lanes b and f). Subsequent Southern analysis suggested that such copies were located outside the $\mathrm{dcm}$ region (data not shown). Finally, the weak additional hybridization signals observed with the IS1355-specific probe in total DNA of strains DM2, DM4, DM13 and GJ21 (Fig. 3a, lanes b, c, f and g) suggested that more divergent IS1355-like sequences were also present in these strains.

The hybridization data were used to construct physical maps of the $\mathrm{dcm}$ region in the different strains, and these are shown in Fig. 5. In summary, six different patterns of organization were observed. The minimal structure present in all strains consisted of a conserved core region of $5.6 \mathrm{~kb}$, which contains the genes $d c m R, d c m A$, orf 353 and orf192 as well as IS1357. The organizational classes differ from each other with respect to the copy number and the location of additional insertion sequences flanking the conserved core region.

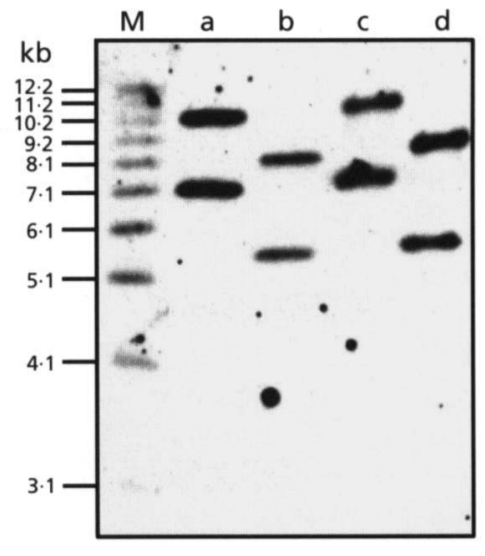

Fig. 4. Detection of a second copy of the conserved core region in Pseudomonas sp. DM1 and DM3. Southern analysis with a DIG-labelled probe of dcmA of total DNA of strain DM1 (lanes a and $b$ ) and DM3 (lanes $c$ and d) digested with Pstl (lanes a and $c$ ) and $B g / l l$ (lanes $b$ and $d$ ), respectively.

\section{Investigation of the transpositional activity of the dcm region}

The $21 \mathrm{~kb}$ HindIII fragment of strain DM4 including the $10 \mathrm{~kb} \mathrm{dcm}$ region defined in the present work was cloned into the suicide vector pSUP202 (Simon et al., 1983; see Table 1), and mobilization of the resulting recombinant plasmid pME1874 into several Methylobacterium $\mathrm{dcm}$ strains was attempted. In no instance, however, could transconjugants be obtained that displayed the DCMutilization phenotype, indicating the inability of the $\mathrm{dcm}$ region to transpose under the conditions of the experiment (M. Schmid-Appert \& D. Gisi, unpublished results).

\section{DISCUSSION}

The three insertion sequences IS1354, IS1355 and IS1357 of Methylobacterium sp. strain DM4 can be ascribed to class I of transposable elements (Kleckner, 1981), but clearly belong to different groups on the basis of their sequence. A close association of three different insertion sequences on a short segment of DNA, as in the present case, has rarely been observed. However, many genes encoding putative transposases similar to IS1357 and especially to IS1355 of strain DM4 (Table 3) were found in the cyanobacterium Synechocystis sp. PCC 6803. In one instance at least, ORFs in the Synechocystis genome (ORFs sll0665-sll066) encoding polypeptides similar to those encoded by IS1355 were located immediately adjacent to an ORF (sll0667, see Table 3 ) similar to the C-terminal end only of Orf411 encoded by IS1357. This suggests that in Synechocystis sp. PCC 6803, an element similar to IS1355 inserted into a sequence similar to IS1357.

The observed accumulation of insertion sequences in the gene region involved in DCM degradation is suggestive 


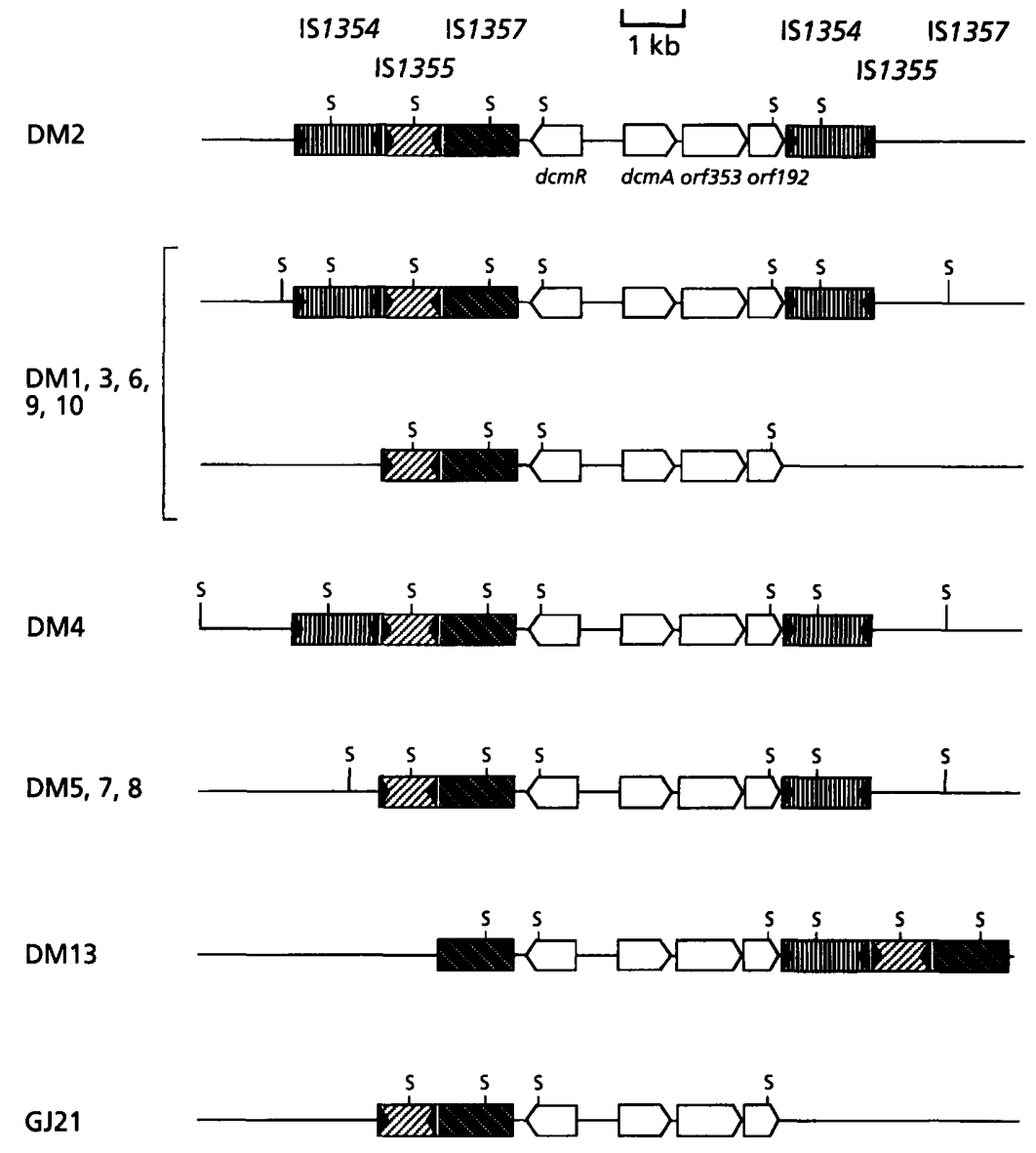
Fig. 5. Genetic organization of the $d c m$ region in DCM-utilizing methylotrophs with a type A DCM dehalogenase. Insertion sequences are shown as hatched boxes. Black triangles indicate the inverted repeats at the ends of IS1354 and IS1355. dcmA, $\mathrm{dcmR}$, orf353 and orf192 are shown as white arrows. The position of Sall sites (S) are indicated.

of a functional association between both types of genes. In addition to their ability to self-transpose during translocation to a foreign genetic context, IS elements can also play a role in gene activation (Galas \& Chandler, 1989). In the present case, activation of $\mathrm{dcm}$ gene expression mediated by a promoter or regulation element internal to the insertion sequence is unlikely, since the upstream sequences of $\mathrm{dcm}$ genes are separated from the insertion sequences by the $\mathrm{dcm}$ genes themselves (Fig. 1).

Evidence for the location of specific catabolic genes on transposons is available for a number of systems (reviewed by Van der Meer et al., 1992; Wyndham et al., 1994), including several examples where the catabolic genes propagated by these elements encode dehalogenating enzymes. The chlorobenzene transposon Tn5280 of Pseudomonas sp. strain P51 is a typical representative of a class I composite transposon. It contains a bacterial dehalogenase gene flanked by two identical copies of an insertion sequence (Van der Meer et al., 1991). Nevertheless, flanking insertion sequences do not always lead to mobility of the associated catabolic genes. For example, the DNA fragment containing the genes involved in 2,4,5-trichlorophenoxyacetic acid in Burkholderia (Pseudomonas) cepacia AC1100 were flanked by two copies of IS931, suggesting a possible class I composite transposon structure. The corresponding DNA fragment, however, could not be demonstrated to be mobile (Haugland et al., 1990). More unusual types of mobile genetic elements involved in dehalogenation processes have also been described. These include the DEH element of Pseudomonas putida PP3 and a mobile DNA segment of Xanthobacter autotrophicus GJ10 that contains IS1247. Both elements are associated with a gene encoding a haloacid dehalogenase (Thomas et al., 1992; van der Ploeg et al., 1995), and they transpose as genetic units of variable length. Whereas the structure of the $D E H$ element remains illdefined, that of strain GJ10 was shown to involve only one flanking copy of IS1247.

The occurrence of two identical copies of IS1354 directly flanking genes involved in DCM utilization in strain Methylobacterium sp. strain DM4 suggested at first that the genes spanned by the two copies, including the two insertion sequences IS1355 and IS1357, represent a class I composite transposon. Alternatively, the gene arrangement observed in the $\mathrm{dcm}$ region of DM4 may have been produced by cointegrate formation or by homologous recombination (Galas \& Chandler, 1989). The presence of different target site duplications flanking the two copies of IS1354, however, argues against such events having taken place in the genome of DM4. Indeed, not all the DCM-utilizing strains which have been characterized contain two copies of IS1354 (Fig. 5). Of course, the analysis of the arrangement of insertion sequences in the $\mathrm{dcm}$ region of Methylobacterium sp. 
strain DM4 and of other related methylotrophic DCM utilizers cannot by itself explain the mechanism by which the $\mathrm{dcm}$ region was acquired and distributed among methylotrophs. Experiments to observe or induce the transposition of the $\mathrm{dcm}$ region have not been successful so far. Nevertheless, the occurrence in many DCM-utilizing methylotrophs of a highly conserved DNA fragment featuring three different insertion elements flanking a core region including the $\mathrm{dcm} A$ gene (Fig. 5) strongly supports the idea that the $d \mathrm{~cm}$ region was transposed in the past.

\section{ACKNOWLEDGEMENTS}

This work was supported by a grant from the Swiss Federal Institute of Technology, Zürich, Switzerland.

\section{REFERENCES}

Altschul, S. F., Gish, W., Miller, W., Myers, E. W. \& Lipman, D. J. (1990). Basic local alignment search tool. J Mol Biol 215, 403-410.

Ausubel, F. M., Brent, R., Kingston, R. E., Moore, D. D., Seidman, J. G., Smith, J. A. \& Struhl, K. (1997). Current Protocols in Molecular Biology. New York: Greene Publishing Associates \& Wiley.

Bader, R. \& Leisinger, T. (1994). Isolation and characterization of the Methylophilus sp. strain DM11 gene encoding dichloromethane dehalogenase/glutathione $S$-transferase. J Bacteriol 176, 3466-3473.

Brunner, W. B., Staub, D. \& Leisinger, T. (1980). Bacterial degradation of dichloromethane. Appl Environ Microbiol 40, 950-958.

Chandler, M. \& Fayet, O. (1993). Translational frameshifting in the control of transposition in bacteria. Mol Microbiol 7, 497-503.

Chen, C. W., Yu, T.-W., Chung, H.-M. \& Chou, C.-F. (1992). Discovery and characterization of a new transposable element, Tn4811, in Streptomyces lividans 66. J Bacteriol 174, 7762-7769.

Coque, J. J. R., Enguita, F. J., Martin, J. F. \& Liras, P. (1995). A twoprotein component $7 \alpha$-cephem-methyloxylase encoded by two genes of the cephamycin C cluster converts cephalosporin $\mathrm{C}$ to 7 methoxycephalosporin C. J Bacteriol 177, 2230-2235.

Coucheron, D. H. (1993). A family of IS1031 elements in the genome of Acetobacter xylinum: nucleotide sequences and strain distribution. Mol Microbiol 9, 211-218.

Daube, G., Simon, P. \& Kaeckenbeeck, A. (1993). IS1151, an IS-like element of Clostridium perfringens. Nucleic Acids Res 21, 352.

De Meirsman, C., Van Soom, C., Verreth, C., Van Gool, A. \& Vanderleyden, J. (1990). Nucleotide sequence analysis of IS427 and its target sites in Agrobacterium tumefaciens T37. Plasmid 24, 227-234.

Doronina, N. V., Braus-Stromeyer, S. A., Leisinger, T. \& Trotsenko, Y. A. (1995). Isolation and characterization of a new facultatively methylotrophic bacterium : description of Methylorhabdus multivorans, gen.nov., sp.nov. Syst Appl Microbiol 18, 92-98.

Doronina, N. V., Sokolov, A. P. \& Trotsenko, Y. A. (1996). Isolation and initial characterization of aerobic chloromethane-utilizing bacteria. FEMS Microbiol Lett 142, 179-183.

Eisen, J. A., Benito, M.-I. \& Walbot, V. (1994). Sequence similarity of putative transposases links the maize Mutator autonomous element and a group of bacterial insertion sequences. Nucleic Acids Res 22, 2634-2636.
Engler-Blum, G., Meier, M., Frank, J. \& Muller, G. A. (1993). Reduction of background problems in nonradioactive Northern and Southern blot analyses enables higher sensitivity than ${ }^{32} \mathrm{P}$ based hybridizations. Anal Biochem 210, 235-244.

Farabaugh, P. J. (1996). Programmed translational frameshifting. Microbiol Rev 60, 103-134.

Ferrante, A. A. \& Lessie, T. G. (1991). Nucleotide sequence of IS402 from Pseudomonas cepacia. Gene 102, 143-144.

Galas, D. J. \& Chandler, M. (1989). Bacterial insertion sequences. In Mobile DNA, pp. 109-162. Edited by D. E. Berg \& M. M. Howe. Washington, DC: American Society of Microbiology.

Galli, R. (1986). Optimierung des mikrobiellen Abbaus von Dichlormethan in einem Wirbelschicht-Bioreaktor. Dissertation, ETH Zürich.

Galli, R. \& Leisinger, T. (1985). Specialized bacterial strains for the removal of dichloromethane from industrial waste. Conserv Recycl 8, 91-100.

Galli, R. \& Leisinger, T. (1988). Plasmid analysis and cloning of the dichloromethane-utilization genes of Methylobacterium sp. DM4. J Gen Microbiol 134, 943-952.

Green, P. N. (1992). The genus Methylobacterium. In The Procaryotes, vol. 3, 2nd edn, pp. 2342-2349. Edited by A. Balows, H. G. Trüper, M. Dworkin, W. Harder \& K.-H. Schleifer. New York: Springer.

Guédon, G., Bourgoin, F., Pébay, M., Roussel, Y., Colmin, C., Simonet, J. M. \& Decaris, B. (1995). Characterization and distribution of two insertion sequences, IS1191 and iso-IS981, in Streptococcus thermophilus: does intergeneric transfer of insertion sequences occur in lactic acid bacteria co-cultures? Mol Microbiol 16, 69-78.

Guerrero, C., Bernasconi, C., Burki, D., Bodmer, T. \& Telenti, A. (1995). A novel insertion element from Mycobacterium avium, IS1245, is a specific target for analysis of strain relatedness. J Clin Microbiol 33, 304-307.

Guilhot, C., Gicquel, B., Davies, J. \& Martin, C. (1992). Isolation and analysis of IS6120, a new insertion sequence from Mycobacterium smegmatis. Mol Microbiol 6, 107-113.

Haugland, R. A., Sangodkar, U. M. X. \& Chakrabarty, A. M. (1990). Repeated sequences including RS1100 from Pseudomonas cepacia AC1100 function as IS elements. Mol Gen Genet 220, 222-228.

Inoue, H., Nojima, H. \& Okayama, H. (1990). High efficiency transformation of Escherichia coli with plasmids. Gene 96, 23-28.

Iversen, T. G., Standal, R., Pedersen, T. \& Coucheron, D. H. (1994). IS1032 from Acetobacter xylinum, a new mobile insertion sequence. Plasmid 32, 46-54.

Kaneko, T., Sato, S., Kotani, H. and 21 other authors (1996). Sequence analysis of the genome of the unicellular cyanobacterium Synechocystis sp. PCC6803. 2. Sequence determination of the entire genome and assignment of potential protein-coding regions. DNA Res 3, 109-136.

Kleckner, N. (1981). Transposable elements in prokaryotes. Annu Rev Genet 15, 341-404.

Kohler-Staub, D., Hartmans, S., Galli, R., Suter, F. \& Leisinger, T. (1986). Evidence for identical dichloromethane dehalogenases in different methylotrophic bacteria. J Gen Microbiol 132, 2837-2843.

Laberge, S., Middleton, A. T. \& Wheatcroft, R. (1995). Characterization, nucleotide sequence and conserved genomic locations of insertion sequence ISRm5 in Rhizobium meliloti. J Bacteriol $177,3133-3142$. 
La Roche, S. \& Leisinger, T. (1990). Sequence analysis and expression of the bacterial dichloromethane dehalogenase structural gene, a member of the glutathione $S$-transferase supergene family. J Bacteriol 172, 164-171.

La Roche, S. \& Leisinger, T. (1991). Identification of $d c m R$, the regulatory gene governing expression of dichloromethane dehalogenase in Methylobacterium sp. strain DM4. J Bacteriol 173, 6714-6721.

Leisinger, T., Bader, R., Hermann, R., Schmid-Appert, M. \& Vuilleumier, S. (1994). Microbes, enzymes and genes involved in dichloromethane utilization. Biodegradation 5, 237-248.

Mazel, D., Bernard, C., Schwarz, R., Castets, A. M., Houmard, J. \& Tandeau de Marsac, N. (1991). Characterization of two insertion sequences, IS701 and IS702, from cyanobacterium Calothrix species PCC7601. Mol Microbiol 5, 2165-2170.

Miller, J. H. (1972). Experiments in Molecular Genetics. Cold Spring Harbor, NY: Cold Spring Harbor Laboratory.

Pearson, W. R. (1996). Effective protein sequence comparison. Methods Enzymol 266, 227-258.

van der Ploeg, J., Willemsen, M., van Hall, G. \& Janssen, D. B. (1995). Adaptation of Xanthobacter autotrophicus GJ10 to bromoacetate due to activation and mobilization of the haloacetate dehalogenase gene by insertion element IS1247. J Bacteriol 177, 1348-1356.

Rezsobhazy, R., Hallet, B., Delcour, J. \& Mahillon, J. (1993). The IS4 family of insertion sequences: evidence for a conserved transposase motif. Mol Microbiol 9, 1283-1295.

Sambrook, J., Fritsch, E. F. \& Maniatis, T. (1989). Molecular Cloning: a Laboratory Manual, 2nd edn. Cold Spring Harbor, NY: Cold Spring Harbor Laboratory.

Schmid-Appert, M. (1996). Untersuchungen zur Regulation des Dichlormethan-Dehalogenase Gens aus Methylobacterium sp. Stamm DM4 und Struktur der angrenzenden DNA-Region. Dissertation, ETH Zürich.

Scholtz, R., Wackett, L. P., Egli, C., Cook, A. M. \& Leisinger, T. (1988). Dichloromethane dehalogenase with improved catalytic activity isolated from a fast-growing dichloromethane-utilizing bacterium. J Bacteriol 170, 5698-5704.

Schuurman, R. \& Keulen, W. (1991). Modified protocol for DNA sequence analysis using Sequenase ${ }^{\circledR}$ 2.0. BioTechniques 10, 185.

Simon, R., Priefer, U. \& Puhler, A. (1983). Vector plasmids for in vitro and in vivo manipulation of Gram-negative bacteria. In Molecular Genetics of the Bacteria-Plant Interaction, pp. 98-106. Edited by A. Pühler. Berlin: Springer.

Soto, M. J., Zorzano, A., Olivares, J. \& Toro, N. (1992). Sequence of ISR 4 from Rhizobium meliloti strain GR4. Gene 120, 125-126.

Stucki, G., Gälli, R., Ebersold, H.-R. \& Leisinger, T. (1981). Dehalogenation of dichloromethane by cell extracts of Hyphomicrobium DM2. Arch Microbiol 130, 366-371.

Thomas, A. W., Slater, J. H. \& Weightman, A. J. (1992). The dehalogenase gene debl from Pseudomonas putida PP3 is carried on an unusual mobile genetic element designated $D E H$. J Bacteriol 174, 1932-1940.

Van der Meer, J. R., Zehnder, A. J. B. \& de Vos, W. M. (1991). Identification of a novel composite transposable element, Tn5280, carrying chlorobenzene dioxygenase genes of Pseudomonas sp. strain P51. J Bacteriol 173, 7077-7083.

Van der Meer, J. R., de Vos, W. M., Harayama, S. \& Zehnder, A. J. B. (1992). Molecular mechanisms of genetic adaptation to xenobiotic compounds. Microbiol Rev 56, 677-694.

Wood, M. S., Byrne, A. \& Lessie, T. G. (1991). IS406 and IS407, two gene-activating insertion sequences from Pseudomonas cepacia. Gene 105, 101-105.

Wyndham, R. C., Cashore, A. E., Nakatsu, C. H. \& Peel, M. C. (1994). Catabolic transposons. Biodegradation 5, 323-342.

Yates, J. R., Cunningham, R. P. \& Holmes, D. S. (1988). IST2: an insertion -sequence from Thiobacillus ferrooxidans. Proc Natl Acad Sci USA 85, 7284-7287.

Received 31 December 1996; revised 27 March 1997; accepted 8 April 1997. 